Document downloaded from:

http://hdl.handle.net/10251/36230

This paper must be cited as:

Rodríguez Abad, I.; Martínez Sala, RM.; Díez Barra, R.; Capuz Lladró, R. (2013).

Assessment of the dielectric anisotropy in timber using the nondestructive GPR technique. Construction and Building Materials. 38:903-911. doi:10.1016/j.conbuildmat.2012.09.052.

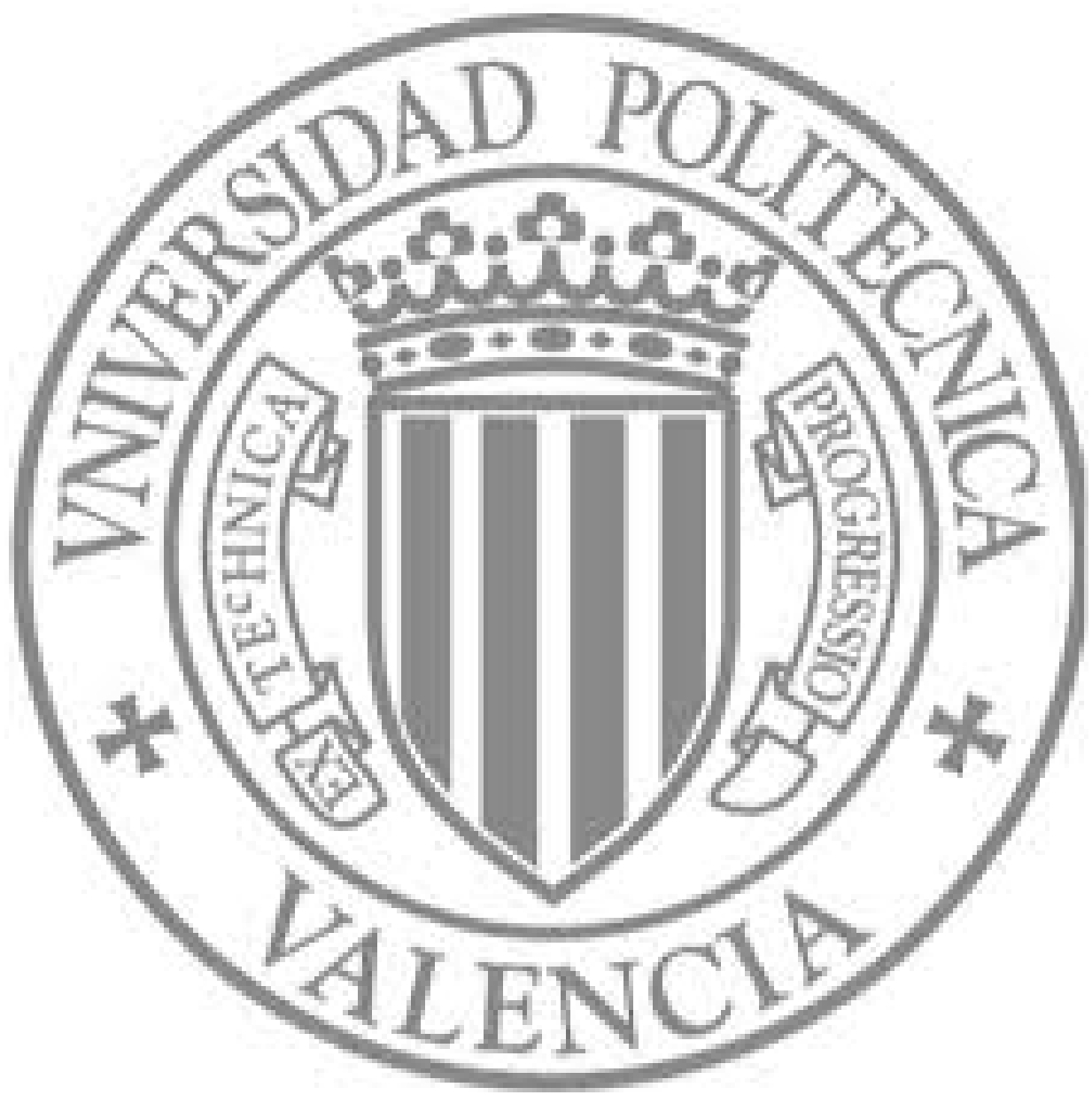

The final publication is available at

http://dx.doi.org/10.1016/j.conbuildmat.2012.09.052

Copyright Elsevier 


\title{
Assessment of the dielectric anisotropy in timber using the
}

\section{nondestructive GPR technique}

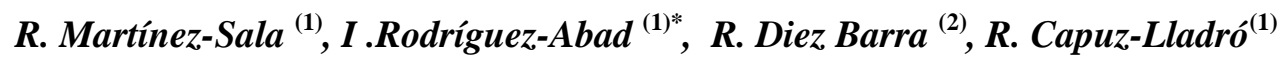 \\ ${ }^{(1)}$ Universidad Politécnica de Valencia, Camino de Vera s/n 46022, Valencia, España, isrodab@upvnet.upv.es \\ ${ }^{(2)}$ Laboratorio de Estructuras. Instituto Nacional de Investigaciones Agrarias (INIA). Av. P. Huidobro, 28040. Madrid, España.
}

(*) Corresponding autor: isrodab@upvent.upv.es

\begin{abstract}
In the realm of architecture Ground-penetrating radar has been used as nondestructive technique to assess physical properties of wood structures in situ. However, a better understanding of the dielectric anisotropy of timber is needed to develop this application. An experiment was conducted on samples of sawn timber of different species (densities) to study their dielectric responses according to the grain directions using a GPR with a $1,6 \mathrm{GHz}$ antenna. Interesting differences were found: the propagation velocities, as well as the amplitudes of the direct and reflected waves always presented lesser when the electric field was longitudinal to the grain than when transverse. But when the field was propagated in whatever transverse direction some of those parameters not differ greatly.
\end{abstract}

Keywords: Ground-penetrating radar, timber, dielectric properties, anisotropy, wave parameters

\section{Introduction}

A considerable number of historic building structures in Spain are made of timber and the need of preservation is increasingly significant. Currently, several nondestructive (NDT) and minor-destructive (MDT) techniques are used in situ for assessing the physical and mechanical properties of wood structures, as reported in [1]. These include stress waves and transverse vibration techniques [2-4] and impulse radar that are also used to inspect other materials such as masonry and concrete. In addition, there are specific NDT and MDT methods for wood, such as the screw withdrawal, the Pilodyn test [5] and the micro-drilling resistance tool [6]. Some of these techniques can be used for in situ evaluation of timber structures, including the transverse vibration technique and impulse radar, also known as Ground-penetrating radar (GPR). 


\subsection{Ground-penetrating radar}

GPR, which uses electromagnetic radiation in the microwave spectrum, is becoming increasingly successful and many effective radar surveys are being carried out in highly diverse fields of application. In architecture GPR has been applied with interesting results in assessing the state of concrete and masonry buildings [710]. Moreover, some works have found that GPR has a promising future as a NDT method for investigating structures or buildings of great historic and cultural value [11 and 12]. Several recently published papers have shown that GPR can be used for the inspection and diagnosis of timber, especially when said timber forms part of a structure or building [13-15], and for assessing physical parameters such as moisture content, density, etc. [16-19].

The general principle of GPR sounding, based on the propagation of electromagnetic impulses in solids, is described in text books [20]. Although a complex topic, GPR can be simplified for most practical structural testing purposes [21 and 22]. GPR equipment is composed of an electromagnetic waves pulse generator, transmitting $\left(\mathrm{T}_{\mathrm{X}}\right)$ and receiving antennas $\left(\mathrm{T}_{\mathrm{R}}\right)$, and a control unit for recording and processing signals. Waveforms are transmitted into the material using an antenna coupled to the surface and propagate through the material as depicted in Fig. 1. GPR signal frequencies are typically between $500 \mathrm{MHz}$ and $2.5 \mathrm{GHz}$ for practical applications with hand-held antennas.

The electromagnetic response of the medium, consisting of all the reflected waves, is then recorded, processed and analysed to measure the travel time and amplitude of the direct and reflected electromagnetic waves. The analysis of the recorded signals can give physical and/or geometrical information about the material.

Generally, GPR measurements consist of recording a profile by passing the antenna along a specimen to generate a specimen length-depth map of internal reflections. This map, named radargram, can be interpreted to indicate the presence of electromagnetic contrast, that is, change of the material dielectric properties at the interfaces. 


\subsection{Anisotropy of wood}

Tree stems are made of wood which is an anisotropic material meaning that it exhibits different properties in three mutually perpendicular directions or planes. This is due to the way in which trees form and organize wood cells as they grow. Wood cells have a small diameter relative to their length and occur with their length parallel to the tree height (longitudinal direction, parallel to the grain) so their diameters are in the plane of the diameter (transverse direction, perpendicular to the grain) of the tree. Over a growing season wood cells are laid down as concentric circles of earlywood and latewood cell forms that comprise an annual ring as seen in the transverse direction. Because of this circular organization and formation of ray tissue that forms in the radial direction through these rings, properties along the radius of the stem diameter differ from those in a direction perpendicular to the radius or tangential to the circular growth ring. Most physical, mechanical and chemical properties of wood differ among the longitudinal, radial and tangential directions (Fig. 2) with the greatest difference between the longitudinal and the radial or tangential directions. The difference between the latter two is relatively small and they are often referred to collectively as the transverse direction.

\subsection{Dielectric properties of wood}

The dielectric properties of a material describe the interaction of the material with electric fields. When wood is placed under an alternating electric field, its dielectric behaviour is governed by frequency of the field and wood density, moisture content, grain direction; and chemical composition; cellulose, lignin and hemicelluloses [23]. The applied electric field aligns randomly oriented dipoles in a direction opposite to that of the electric field. In this ordered configuration, energy supplied by the field is stored in molecules in the form of potential energy. The amount of energy that can be stored in the material is related to the dielectric constant $\left(\varepsilon^{\prime}\right)$. The portion of the stored energy that is dissipated in the form of heat is related to the dielectric loss ( $\left.\varepsilon^{\prime \prime}\right)$. Finally, the complex dielectric constant $(\varepsilon)$ is given by:

$$
\varepsilon=\varepsilon^{\prime}-i \varepsilon^{\prime} \quad \text { (eq. 1) }
$$

The dielectric constant $\left(\varepsilon^{\prime}\right)$ can be calculated from GPR recordings in slightly conduction media [21]. The $\varepsilon^{\prime}$ 
of wood can be distinguished along the three orthogonal grain directions: $\varepsilon_{/ /}^{\prime}$ in the longitudinal direction, $\varepsilon^{\prime}{ }_{R}$ in the radial direction, and $\varepsilon_{T}^{\prime}$ in the tangential direction (Fig. 2). This assumes that the electric field vector is oriented in these respective directions. When the electric vector is oriented transverse or perpendicular to the grain without further specification, the notation $\varepsilon_{\perp}^{\prime}$ will be used.

A comprehensive review of the dielectric properties of wood as a function of species, moisture content, anisotropy, temperature and frequency was given in [23-25]. Experiments conducted by different authors on timber of various species and moisture contents show that the longitudinal component is always higher than the transverse components. There also exists a slight difference between the radial and tangential components, but this is negligible compared with the difference between the longitudinal and transverse direction.

The variation in dielectric properties between the longitudinal, radial, and tangential directions is due to the difference in the arrangement of the walls and lumens of wood cells by tree growth and the anisotropy of the chemical components of cell wall substance [26]. The greater dielectric constant in longitudinal direction has been explained in terms of the transition probability of dipole jump to an adjacent site when the field applied to longitudinal direction in contrast to when the electric field was applied in the radial or tangential directions [27]. The chemical composition of wood may also be responsible for the dielectric anisotropy. According to [28], the dielectric properties of wood are strongly influenced by cellulose in the longitudinal direction, whereas the dielectric properties are influenced by lignin in transverse direction.

Previous studies [29-31] found that the longitudinal direction exhibited higher dielectric constant compared to the transverse direction in different species with diverse moisture contents. In addition, [29] and other studies [23 and 32] found that there was little difference in dielectric behaviour when the fields oscillated radially or tangentially for various frequencies and different species of hardwoods and conifers. Recent microwave studies have shown that the difference between the radial and tangential dielectric constants is small [33] with the radial constant being slightly greater. However, this difference is minimal when compared to the longitudinal direction [31]. Some results of the electric measurements [31, 24] conducted at different frequencies, moisture contents and grain directions on five different wood species are given in table 1. 
As wood is a nonhomogeneous material, with a complex fibre-composite structure, it varies in its dielectric properties with grain direction. Therefore, prior to any GPR study in timber, it is necessary to distinguish between differences found in the parameters of the electromagnetic waves which are directly attributable to the anisotropy of wood and those due to variations caused by other phenomena - such as rot, changes in moisture content, etc. In addition, when using this technique to study wooden structures in situ, it is useful to know whether the GPR findings are comparable, regardless of the direction of oscillation of the electric field with respect to the grain since it is often the case that some surfaces of the beam structure are inaccessible.

The main goal of this study was to analyse the variation of the parameters of the electromagnetic waves in different species of timber as a consequence of dielectric anisotropy. In selecting samples of several species there was no intend to relate the electric properties to species characteristics but only to see differences or similarities in timber.

\section{Material and method}

This research was focused on the analysis of the influence of the dielectric anisotropy of timber on GPR signals emitted with an antenna of $1.6 \mathrm{GHz}$ central frequency using a SIR-10H system (Fig. 3), both developed by Geophysical Survey Systems Inc. (GSSI), while the specimens were at constant moisture content $(M C)$ and temperature.

The design of the GPR antenna determines the direction of the polarisation of the electrical field. In our case (Fig. 4), the antenna radiates an electromagnetic field whose electrical component (E) oscillates perpendicularly to the dipole plane [34]. Therefore, the study presented in this paper analyse the variation occurring in the electromagnetic waves parameters when propagating in different directions relative to the grain by varying the antenna position.

The tests were conducted on 18 timber samples (Tab.2) from 12 species which were chosen among the most commonly commercialized sawn timber in Spain. The size and dimensions were not equal in all specimens, because not all of them are commercially distributed with the same cross section. But that did not mean an obstacle for this study, because the objective was to compare the relative values of the wave parameters obtained for each sample when the electric field had different directions. The density of the samples was 
calculated following the standard [35] and $M C$ was determined based on the ovendry weight standard [36]. All the tests were carried out when the $M C$ was at hygroscopic equilibrium and $24^{\circ} \mathrm{C}$ in a closed chamber to prevent the loss of $M C$ during the measurement.

The tests were designed to examine the variations occurring in electromagnetic wave velocities, amplitudes, and spectra when the electric field was propagated in a number of different directions with respect to the grain. For this purpose, two types of test were performed. In test 1, Longitudinal versus Transverse Test, the wave parameters were recorded when the electric field was longitudinal or transverse to the grain. To achieve this, the antenna was placed on the face in two transverse directions to each other: Face//, where the electrical field was longitudinal to the grain and Face $\perp$, where the oscillating electrical field was transverse to the grain, Fig. 5a and $5 b$ respectively.

In test 2, Transverse Test, the antenna was placed on the edges and the squared-ends of the samples (Fig. 5c and 5d respectively), where the electric field was transverse to the grain in both cases. As each studied sample showed different growth ring patterns - according to the part of the tree from which it was cut - we were able to evaluate the response of the electromagnetic field when propagating in different transverse directions to the grain, both radial and tangential to the growth rings.

The GPR measurements consisted in recording approximately 400 scans by placing the antenna on the centre of the sample surface. No gain function or filtering was applied so as to leave the amplitude values unaltered and perform the readings directly with the raw data. GPR signals were processed and analysed using RADAN NT software (GSSI).

In the recorded signals, the GPR waves may be divided into two parts. The direct wave $(D)$, which corresponded to the energy radiated directly towards the receiver, appeared as the first recorded wave in the trace. It propagated through the initial few centimeters of the samples along the surface on which the antenna was placed. The second part of the signal, the reflected wave $(R)$, was due to energy reflected from the bottom of the sample by the timber-metallic reflector plate interface (Fig. 6).

The value recorded for the two-way travel times and amplitudes for the $D$ wave were always taken at the first positive maximum. To better understand the arrival of the $R$ waves, it was necessary to conduct measurements in each sample and surface with and without a metallic reflector plate. A phase change occurred, when a metallic plate was placed beneath the beam, as it is shown in Fig. 6 (blue line). 
Due to the dimensions of the samples, when the antenna was placed on the edge, the $D$ and $R$ waves appeared separately in time (Fig. 6a). Nevertheless, when the antenna was placed on the face, in some cases, the $D$ and $R$ waves interfered (Fig. 6b). Despite this overlap, the identification of the $R$ wave arrival was possible by comparing the records acquired with or without metallic reflector.

In addition, the $R$ wave arrival identification was complex, since timber presented a low dielectric contrast with air. For all this reasons, times and amplitudes of the $R$ wave measurements were made out of two steps. Firstly, the $R$ arrival time position was identified by comparing the signals with and without a metallic plate beneath the beam (Fig. 6). Secondly, once this point was identified, all readings were performed on the first positive maximum of the $R$ wave, when the record was acquired with a metallic plate, since in this case the reflection coefficient is the highest and therefore this peak was the easiest to identify. Finally, all amplitudes ( $D$ and $R$ ) were normalized relative to the first positive maximum of the $D$ when transmitted through the air which was taken a stable reference.

The dielectric constant of the timber beam, $\varepsilon^{\prime}$, can be computed according to the following equations [21]:

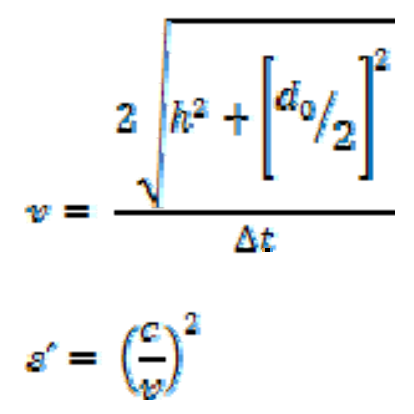

where $v$ is the electromagnetic wave velocity in the beam, $\Delta t$ is the electromagnetic wave two-travel time through the beam, $h$ is the sample thickness and $d_{0}$ is the distance between TX and TR $(5.8 \mathrm{~cm})$, as shown in Fig. 1 and $c$ is the speed of light in free space $\left(c \approx 310^{8} \mathrm{~m} / \mathrm{s}\right)$. 


\section{Results and discussion}

\subsection{Test 1: Longitudinal versus transverse test}

This section analysed how the dielectric behaviour of wood varies - depending on whether the electrical field oscillated in a longitudinal or transverse direction to the grain. Fig. 7 shows the typical traces registered when the field oscillated in transverse (a) and longitudinal to the grain (b). In the case of the longitudinal direction, the reflected wave $\left(R_{/ /}\right)$was always slower than the transverse case $\left(R_{\perp}\right)$. Therefore, the velocity

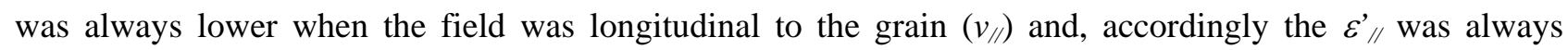
greater in this case (Tab. 3). The values for the longitudinal and transverse dielectric constant for every sample were found to be in the interval $\varepsilon^{\prime} / / \varepsilon_{\perp}^{\prime}=[1.0-1.4]$.

These results are in complete agreement with previous works carried out in Pinus pinaster Ait. with GPR [37] and with those obtained by other authors using lower working frequencies [23, 32 and 38]. It is important to point out that the dielectric constants, $\varepsilon_{/ /}$' and $\varepsilon_{\perp}$ ', cannot be correlated with density, since the better adjustments with densities were found to be with an $\mathrm{R}^{2}<40 \%$.

The normalized amplitudes of the $R\left(A_{R}\right)$ were found to be higher than those of the $D\left(A_{D}\right)$ as it is shown in Tab. 4. This was explained because the thicknesses of the samples were less than the vertical threshold resolution and in addition a metallic reflector plate was placed behind the sample. These resulted in a positive interference as is illustrated in Fig. 7.

When the normalized amplitudes $A_{R}$ and $A_{D}$ were calculated, it was also clear that both showed higher values when the field oscillated transverse $\left(A_{D \perp}\right)$ (Fig. 8a). This pattern of amplitudes behavior was also observed in previous works performed in Pinus pinaster Ait. [39]. Therefore, the obtained wave parameters regarding the amplitudes allowed us to distinguish the different directions of propagation to the grain.

The relationship between the $A_{D}$ and the $A_{R}$ for the longitudinal and transverse directions for each sample is detailed in Tab. 4. The ratio values for the normalized $D$ waves, $A_{D / /} / A_{D \perp}$, ranged from 0.7 to 0.9 and for $R$ waves, $A_{R / /} / A_{R \perp}$ from 0.5 to 0.80 . It is important to emphasize that, regardless of the density and the specie of the samples, they all followed the same trend in all of the wave parameters: velocity, dielectric constant and 
amplitudes. This fact, no differences between densities and species behavior, allow us to say that GPR and 1,6 GHz antenna might be a suitable to identify the longitudinal versus transverse dielectric anisotropy of wood.

In the analysis of the frequency spectra of received signals, it was also found that they generally showed the same spectral behaviour. That is, when comparing the spectra with the signal transmitted to air, it was immediately apparent that a shift had occurred towards the lower frequencies. However, the shift when the field oscillated transverse to the grain was less than when in the longitudinal direction, since the central peak fell between 1.3-1.2 GHz for the transverse direction and around 1.0 GHz for the longitudinal direction (Fig. $8 b$ and $8 c)$.

In addition, the bandwidth and relative amplitudes of the frequency peak were smaller when the field oscillated longitudinal to the grain than in the transverse direction. Although the variation of the central peak amplitude cannot be correlated with density, a trend was observed: the lower the density the greater the difference in the central peak amplitude. For instance, for sample 1 in longitudinal oscillation of the field, the amplitude of the central frequency was 1100 units lower than in transverse oscillation, while for the sample 14 that difference was of 1700 units (Fig. 8b and c). Nevertheless, further studies should be performed to confirm this tendency, since the wave propagation is greatly influenced by $M C$ and the used samples had diverse $M C$ (Tab. 2).

\subsection{Test 2: Transverse test}

This section discusses the results obtained by placing the antenna in several positions but always with the electrical field oscillating transverse to the grain. In this way, as mentioned, the electrical field could be radial or tangential - depending on the sample.

The values obtained for the $v$, and so for $\varepsilon^{\prime}$ of all the samples, were very similar - regardless of the transverse field direction. The typical traces registered when the antenna was placed on the edge and squared ends of the samples 7 and 3 illustrate this result (Fig. 9).

In Tab. 5 the ratio for the velocity values and dielectric constant for the analysed transverse directions when placing the antenna on the edges and the squared-ends are shown. It can be observed that the average value 
$v_{E} / v_{S}$ and $\varepsilon_{E}^{\prime} / \varepsilon_{S}^{\prime}$ was found to be 1 . That means that these two parameters were not affected when the electric field was emitted with a 1,6 GHz central frequency antenna in the different transverse directions.

Fig. 10a shows the $A_{D}$ and the $A_{R}$ as recorded with the antenna located on the edge $(E)$ and the squared-end (S) of each sample. In this case, the $A_{D}$ was always higher than those of the $R$. This was because with the two positions of the antenna used for this test, the $R$ travelled a longer path (Tab. 1) and so was always more attenuated.

In previous works, when the behaviour of Pinus pinaster Ait. timber was analyzed, a slight difference was observed in the $D$. The relationship between the $A_{D}$ with the antenna at the edge and the squared-end was found to be $A_{D E} / A_{D S}=1.10$, regardless of the samples cross section [40]. However, not all the samples analyzed in this research followed the same pattern, since the relation was found to range $A_{D E} / A_{D S}=[0.8-1.2]$ (Tab. 6). Likewise, it was observed that for $A_{R}$ no unique pattern was followed by all the samples, since $A_{R E} / A_{R S}$ ranged from 0.7 to 1.6. Therefore, these two relations provide little reliable information about the capability of the amplitudes of this test to characterise the transverse dielectric anisotropy.

In relation to the signal frequency spectra, it was found that all the samples followed the same spectral behaviour. As it happened in Test 1, there was a shift to low frequencies when compared with the spectrum of the signals transmitted to air.

Fig. 10b and c illustrate the spectra when the antenna was placed on the edge and squared end and these consisted of two maximum peaks located close to $1.2 \mathrm{GHz}$ and $1.7 \mathrm{GHz}$. No pattern was found in these spectra related to the different transverse dielectric anisotropy. For instance, when the antenna was placed on the edge, the electric field oscillated tangentially for the sample 17 and radially for the sample 10 . Nevertheless, they present similar spectral behavior. The only difference between them was found in the amplitude of the first maximum peak; but it was so little that cannot be related to anisotropy, species or density.

\section{Conclusions}

From the results obtained using a 1,6 GHz central frequency antenna it can be concluded that the three wave parameters analysed: propagation velocity, amplitude and spectra frequency differ depending the direction of 
the electrical field relative to the grain, whether longitudinal or transverse. The propagation velocity of the waves detected with this antenna wasalways greater when the electrical field was transverse to the grain of the wood; and so $\varepsilon^{\prime}$ was always lesser. These results completely agree with previous studies and those obtained by other authors working with similar frequencies. The amplitudes of the direct and reflected waves were obtained always smaller when the electrical field was longitudinal to the grain than when transverse. The frequency spectra have similar shapes in all cases. However, when the electrical field was longitudinal to the grain a greater shift to low frequencies occurred in the central frequency. This was accompanied by a further narrowing of the band and a larger reduction in amplitude of the central frequency.

Regarding the different transverse directions to the grain, no differences were observed when the velocities and dielectric constants were analysed for various transverse directions of the electrical field relative to the grain. Nevertheless, the amplitudes were revealed as a useless parameter to identify transverse dielectric anisotropy since no unique pattern for all samples was observed. No special features were identified in the different directions of the transverse spectra that could be associated to anisotropy.

This research represents a worthwhile contribution for the development of a GPR technique for studying the physical properties of timber. The results obtained showed that the longitudinal dielectric wood behaviour versus transverse was clearly identifiable by analyzing the wave parameters of the signals transmitted by means of GPR with an 1,6 GHz central frequency antenna, for all the analysed species, regardless if they were hardwood or softwood. It is necessary to emphasize the practical importance of the result produced for transverse directions. The insignificant differences in wave velocities and dielectric constants observed for various transverse directions can simplify data acquisition. This means that when a beam forming part of a structure is inspected, there will be no significant differences when making an analysis in any of the transverse directions to the grain. This, in turn, means beams do not have to be inspected in the same direction, and this facilitates the acquisition of data because some faces of structural beams are sometimes inaccessible.

Finally, the analysis presented in this paper demonstrates that GPR can be used in the dielectric analysis of wood; and furthermore GPR with its $1,6 \mathrm{GHz}$ antenna is shown to be a tool with a promising future in the nondestructive in situ study of the physical properties of timber. 


\section{Acknowledgements}

On one hand, financial support for the laboratory work was provided by the Spanish Ministry of Science and Innovation under the 2009-2012 national research and development plan through a project entitled: 'Integration of advanced and nondestructive evaluation techniques for structural timber and the restoration and conservation of heritage buildings (BIA2008-00342)'. We would like to thank our colleagues at the materials laboratory of the Escuela Técnica Superior de Ingeniería de Edificación the Universidad Politécnica de Valencia, Spain.

On the other hand, this work is supported partly by the "Programa de Apoyo a la Investigación y Desarrollo (PAID-00-11)" of the Universitat Politècnica de València. The authors would like to acknowledge the contribution of Dr Briggs of the School of Forest Resources at the University of Washington, Seattle (USA).

\section{References}

[1] Kasal B, Tannert T. In situ assessment of structural timber. RILEM State of the Art Report; 2001.

[2] Peterson M L, Gutwoski R M. Evaluation of the structural integrity of timber bridges. NDT\& E International 1999; 32: 43-48.

[3] Wang X, Wacker J P, Morison A M, Forsman J W, Erickson J, Ross R J. Nondestructive assessment of single span timber bridge using vibration-based method. Research Paper FLP-RP-627. USDA Forest Service. Forest Products Laboratory Madison, WI; 2005.

[4] Emerson R, Pollock D, Mclean D, Fridley K, Pellerin R, Ross R. Ultrasonic inspection of large bridge timbers. Forest Products Journal 2002; 52, 9:88-95.

[5] Ross R J, Pellerin R F. Nondestructive testing for assessing wood members in structures-A review. Generic Technical Report FPL-GTR-70. USDA Forest Service. Forest Products Laboratory Madison, WI; 1994.

[6] Brashaw B, Vatalaro R, Wacker J, Ross R. Condition assessment of timber bridges. 1. Evaluation of micro-drilling resistance tool. Research Paper FLP-GTR-159. USDA Forest Service. Forest Products Laboratory Madison, WI; 2005.

[7] Sbartai Z M, Laurens S, Balayssac J P, Ballivy G, Arliguie G. Effect of concrete moisture on radar signal amplitude. ACI Materials Journal 2006; 103, 6: 419-426. 
[8] Viriyametanont K, Laurens S, Klysz G, Balayssac J P, Arliguie G. Radar survey of concrete elements: Effect of concrete properties on propagation velocity and time zero. NDT \& E International 2008; 41, 3: 198207.

[9] Pérez V, García F, Rodríguez-Abad I. GPR evaluation of the damage found in the reinforced concrete base of a block of flats: A case study. NDT \& E International 2008; 41, 5: 341-353.

[10] Maierhofer C, Wostmann J, Hennen C. Non-destructive investigation of complex historic masonry structures with impulse radar. Proceedings of the International Symposium on Nondestructive Testing in Civil Engineering; 2003.

[11] García F, Blanco M, Rodríguez-Abad I, Martínez-Sala R, Ausina I, Marco J B, Conesa J L M. GPR technique as a tool for cultural heritage restoration: San Miguel de los Reyes Hieronymite Monastery, 16th century (Valencia, Spain). Journal of Cultural Heritage 2007; 8, 1: 87-92.

[12] Ramírez M, García F, Rodríguez-Abad I, Martínez-Sala R, Benlloch J. Ground-penetrating radar survey for subfloor mapping and analysis of structural damage in the Sagrado Corazón de Jesús Church, Spain. Archaeological Prospection 2008; 15, 4: 285-292.

[13] Rodríguez-Abad I, Martínez-Sala R, Capuz-Lladró R, García-García F, Cabrelles L. Application of the Non-Destructive Ground-Penetrating Radar (GPR) Technique to the Restoration Works of a Timber Structure. Proceedings of the I Congreso Internacional de Investigación en Edificación; 2009.

[14] Tannert T, Kasal B, Anthony R. RILEM TC 215 In situ assessment of structural timber: Report on activities and application of assessment methods. Proceedings of the World Conference Timber Engineering; 2010.

[15] Capuz Lafarga L, Capuz-Lladró R, García-García F, Rodríguez-Abad I, Martínez-Sala R, Díez-Barra R. Evaluación de la madera estructural para la rehabilitación de las Naves Cros (Valencia, España) por medio de diferentes técnicas no destructives. Proceedings of the 11 Congresso Ibero-Latinoamericano da Madeira na Construção; 2011.

[16] Rodríguez-Abad I, Martínez-Sala R, Tort I, García-García F, Díez R, Capuz-Lladró R. Estudio del contenido de humedad de vigas de madera de distintas especies por medio de la técnica no destructiva de georradar. Proceedings of the IV Congreso Nacional y I Congreso Iberico de Agroingenieria; 2007.

[17] Rodríguez-Abad I, Martínez-Sala R, García-García F, Capuz-Lladró R, Díez R. A non-destructive method for the evaluation of density and moisture content in sawn timber structures by GPR. Proceedings of the $12^{\text {th }}$ International Conference on Ground Penetrating Radar; 2008. 
[18] Rodríguez-Abad I, Martínez-Sala R, García-García F, Capuz-Lladró R. Non-destructive methodologies for the evaluation of moisture content in sawn timber structures: Ground penetrating radar and Ultrasound technique. Near Surface Geophysics 2010; 8:475-482.

[19] Rodríguez-Abad I, Martínez-Sala R, Capuz Lladró R, Díez Barra R, García-García F. Assessment of the variation of the moisture content in the Pinus pinaster Ait. using the nondestructive GPR technique. Materiales de Construcción 2011; 61,301: 143-156.

[20] Daniels D.J. Ground-penetrating radar. London, UK: Institute of Electrical Engineers; 2004.

[21] Pérez V. Radar del subsuelo. Evaluación en arqueología y en patrimonio histórico-artístico. PhD Thesis of the Universidad Politécnica de Cataluña, Barcelona, Spain; 2001.

[22] Rodríguez-Abad I. Evaluación de la técnica no destructiva del georradar para la inspección, diagnóstico y análisis resistente de la madera. PhD Thesis of the Universidad Politécnica de Valencia, Valencia, Spain; 2010.

[23] Torgovnikov G I. Dielectric properties of wood and wood-based materials. Springer Verlag; 1993.

[24] James W L. Dielectric properties of wood and hardboard. Variation with temperature, frequency, moisture content and grain direction. Research Paper FLP-245. USDA Forest Service. Forest Products Laboratory Madison, WI; 1977.

[25] Bucur V. Non-destructive characterization and imaging of wood. Springer Verlag Series in Wood Science; 2003.

[26] Norimoto M, Hayashi S, Yamada T. Anisotropy of dielectric constant in coniferous wood. Holzforschung 1978; 32, 5: 167-173.

[27] Norimoto M, Yamada T. The dielectric properties of wood IV. On the dielectric dispersion of ovendried wood. Wood Research 1970; 50:36-49.

[28] Norimoto M, Yamada T. The dielectric properties of wood VI, on the dielectric properties of chemical constituents of wood and the dielectric anisotropy of wood. Wood Research 1972; 52:30-33.

[29] Chazelas J L. Caractéristiques pyhisques et mécaniques locales du bois dans la zone des noeuds. PhD Thesis of the Université Blaise Pascal, Clermont Ferrand, France; 1991.

[30] Franchois A, Pineiro Y, Lang R H. Microwave permittivity measurements of two conifers. IEEE Transactions on geosciences and remote sensing 1998; 36, 5:1384-1395.

[31] Sahin H, Nürgul A. Dielectric properties of hardwood species at microwave frequencies. Journal of Wood Science 2004; 50: 375-380. 
[32] Kabir M F, Daud W M, Khalid K, Sidek H A A. Effect of moisture content and grain direction on the dielectric properties of rubber wood at low frequencies. Holzforschung 1998; 52: 546-552.

[33] Daian G, Taube A, Birnboim A, Shramkov Y, Daian M. Measuring the dielectric properties of wood at microwave frequencies. Wood Science and Technology 2005; 39,3: 215-223.

[34] Duke S. Calibration of ground penetrating radar and calculation of attenuation and dielectric permittivity versus depth. PhD Thesis of the Colorado School of Mines, USA; 1990.

[35] UNE 56531:1977. Physical-mechanical characteristics of wood. Determination of specific weight.

[36] UNE-EN 13183-1:2002. Moisture content of a piece of sawn timber. Part 1: Determination by oven dry method

[37] Rodríguez-Abad I, Martínez-Sala R, Capuz-Lladró R, García-García F. Analysis of dielectric anisotropy in Pinus pinaster Ait by the GPR technique. Proceedings of the $5^{\text {th }}$ International Workshop on Advanced Ground Penetrating Radar; 2099.

[38] Kabir M F, Daud W M, Khalid K B, Sidek A H A. Equivalent circuit modeling of the dielectric properties of rubber wood at low frequency. Wood and Fiber Science 2000; 32, 4: 450-457.

[39] Rodríguez-Abad I, Martínez-Sala R, García-García F, Capuz-Lladró R. Wave parameter analysis of dielectric anisotropy in maritime pine timber using GPR. Proceedings of the International Congress on Ground-penetrating radar; 2010.

[40] Rodríguez-Abad I, Martínez-Sala R, García-García F, Capuz-Lladró R, Díez Barra R. Nondestructive characterization of Maritime Pine sawn timber dielectric anisotropy by means of GPR. Proceedings of the International Workshop on Ground-penetrating radar; 2011. 


\section{Figure captions}

Fig. 1. (a) Schematic principle of GPR measurement using ground-coupled antennas and (b) GPR profile on a timber beam.

Fig. 2. Principal axes of wood with respect to grain direction and growth rings: longitudinal (//), transverse $(\perp)$, radial $(\mathrm{R})$ and tangential $(\mathrm{T})$.

Fig. 3. (a) SIR-10H equipment connected to a $1,6 \mathrm{GHz}$ antenna (GSSI) and GPR measurements on timber joist; antenna placed on edge (b) and face (c) timber joists while acquisition of records.

Fig. 4. Diagram of the electrical field oscillating transverse to the dipole of the 1,6 GHz antenna (GSSI).

Fig. 5. Positions of the antenna with respect to the grain. Antenna placed on the: (a) Face//, (b) Face $\perp$, (c) edge and (d) squared-end.

Fig. 6. Phase change of $R$ wave when the antenna was placed on the edge (a) and the face (b) of sample 2. The blue line is used for the trace registered with a metallic reflector plate beneath the beam and the grey line without.

Fig. 7. Results from Test 1: Comparison between the typical radar section recorded when the electrical field oscillated transverse (a) and longitudinal (b) to the grain for sample 7 and typical traces from both antenna acquisitions for sample 2 (c) and sample 13 (d).

Fig. 8. Results from Test 1: Normalized amplitudes of the $D$ and $R$ waves when the field oscillated longitudinal or transverse to the grain (a); Frequency spectrum when the electrical field oscillated longitudinal or transverse to the grain of the samples 1 (b) and 14 (c).

Fig. 9. Results from Test 2: Comparison between the typical radar section recorded with the antenna placed on the edge (a) and squared end (b) for sample 7 and typical traces from both antenna acquisitions for sample 3 (c and d).

Fig. 10. Results from Test 2: Normalized amplitudes of the $D$ and $R$ waves when the field oscillated transverse to the grain (a); Frequency spectrum when the electrical field oscillated transverse to the grain, placing the antenna on edge or squared end of sample 10 (b) and 17 (c). 




Figure 1

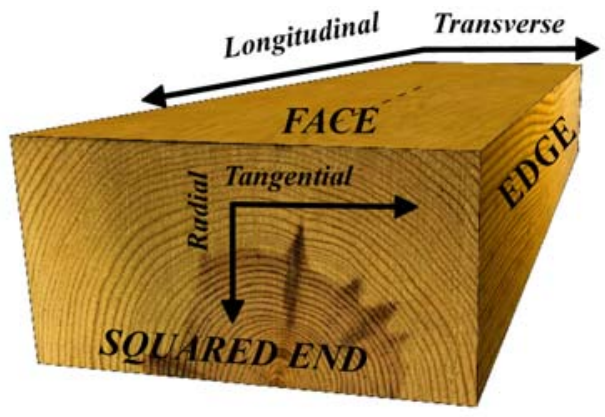

Figure 2 



Figure 3
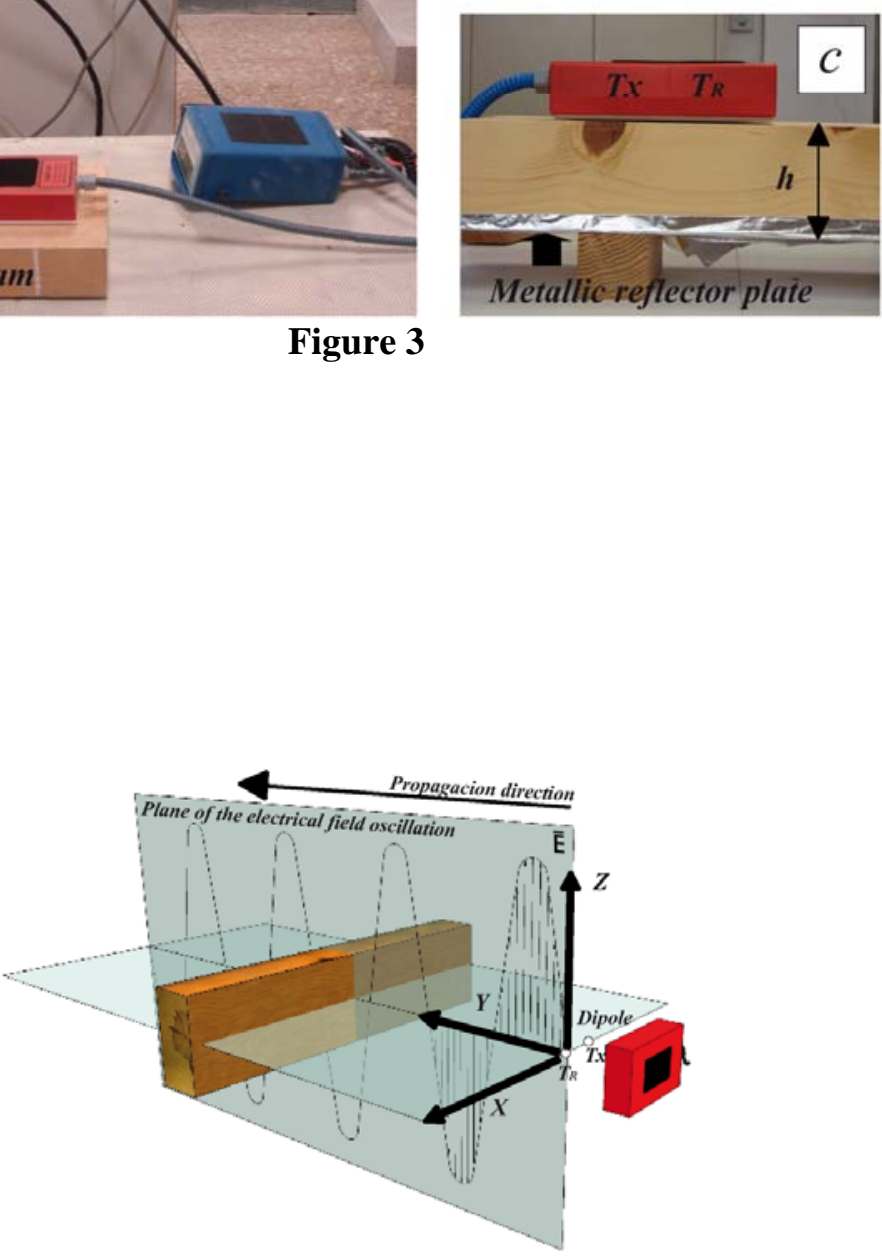

Figure 4 


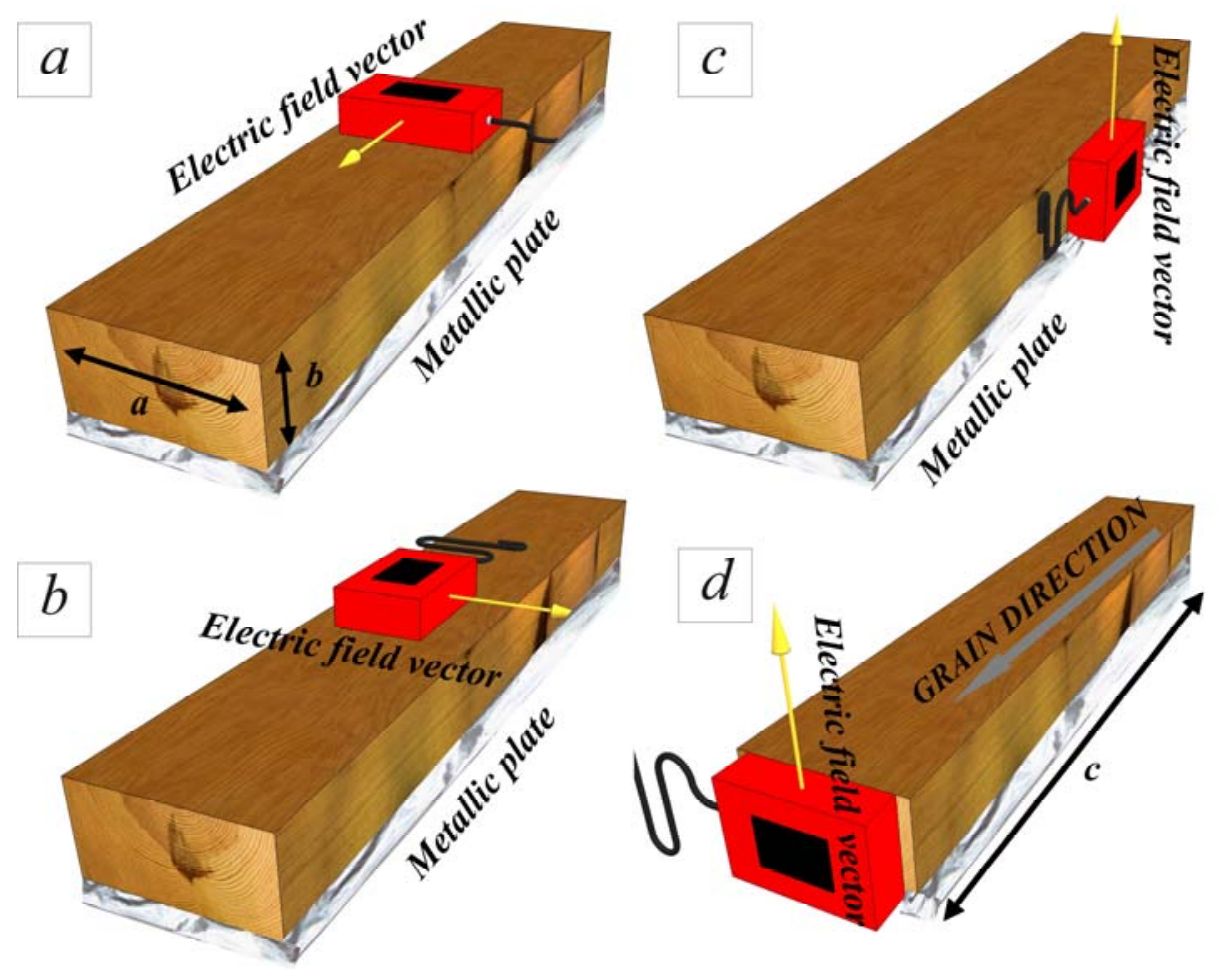

Figure 5

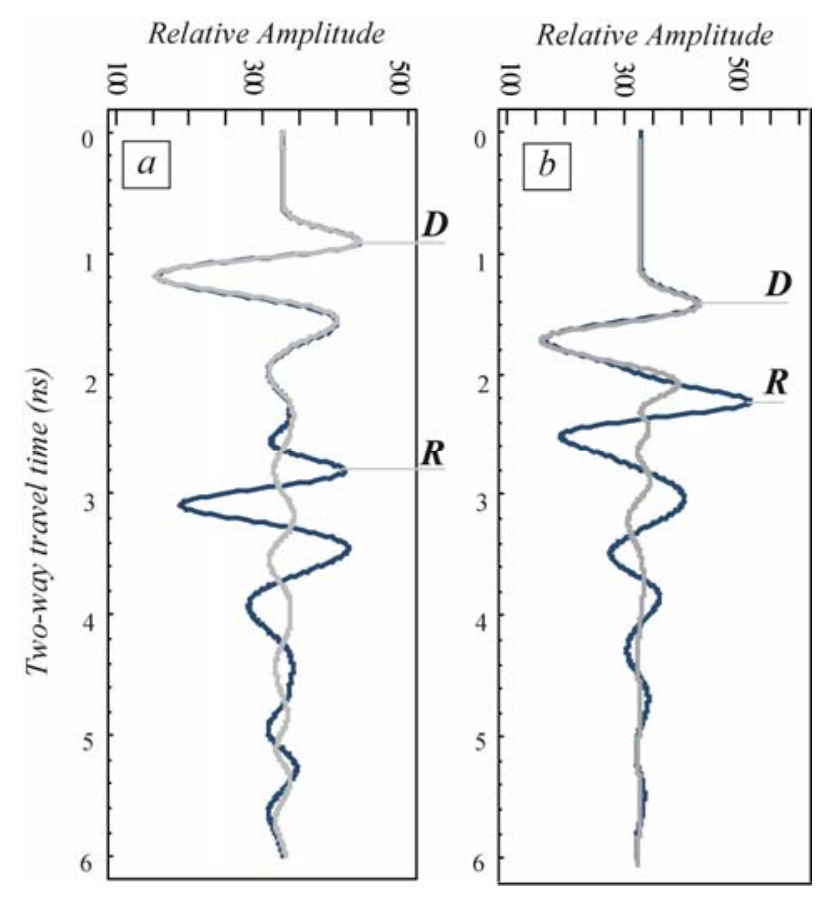

Figure 6 

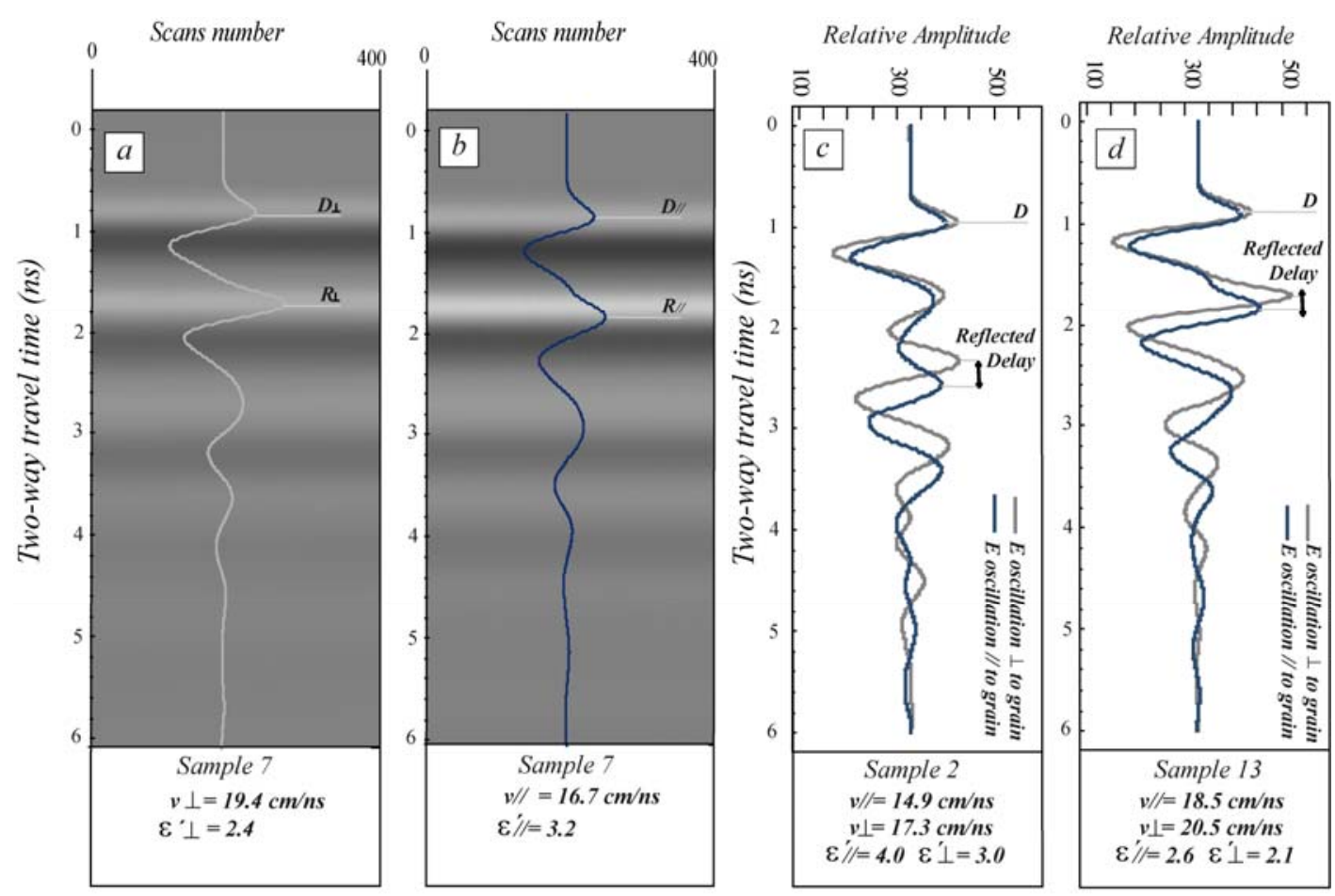

Figure 7 

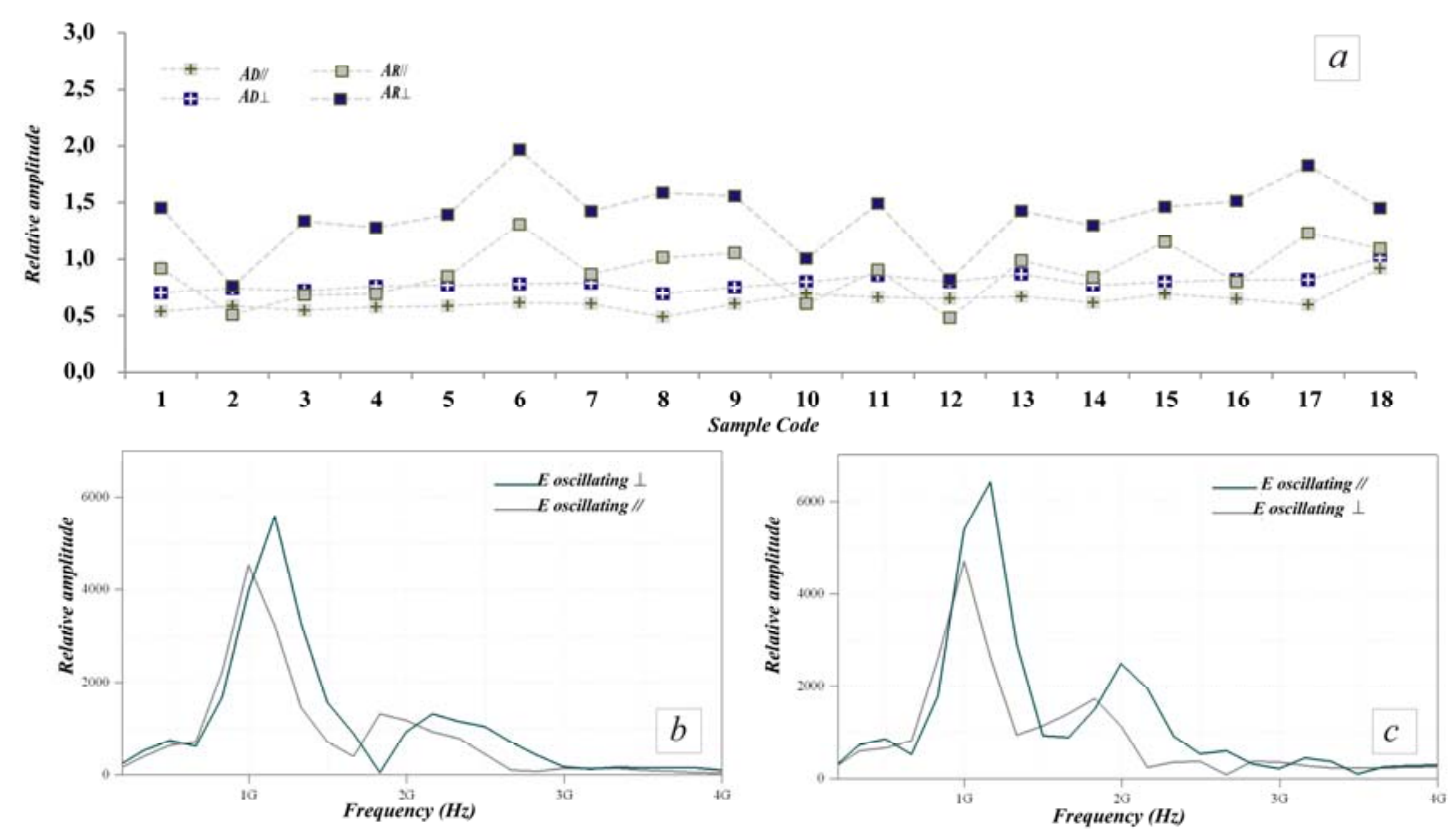

Figure 8
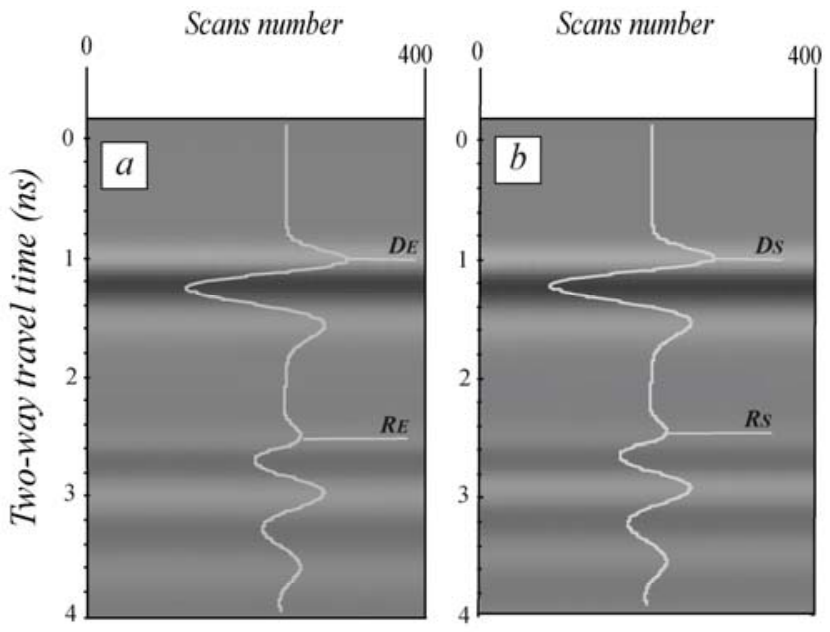

Sample 7

$v E=21.5 \mathrm{~cm} / \mathrm{ns} \quad v S=20.4 \mathrm{~cm} / \mathrm{ns} \quad \varepsilon_{E}^{\prime}=1.9 \quad \varepsilon \dot{S}=2.2$

Sample 3

$v E=16.1 \mathrm{~cm} / \mathrm{ns} \quad v S=15.5 \mathrm{~cm} / \mathrm{ns} \quad \varepsilon_{E}^{\prime}=3.5 \quad \varepsilon \dot{S}^{\prime}=3.7$

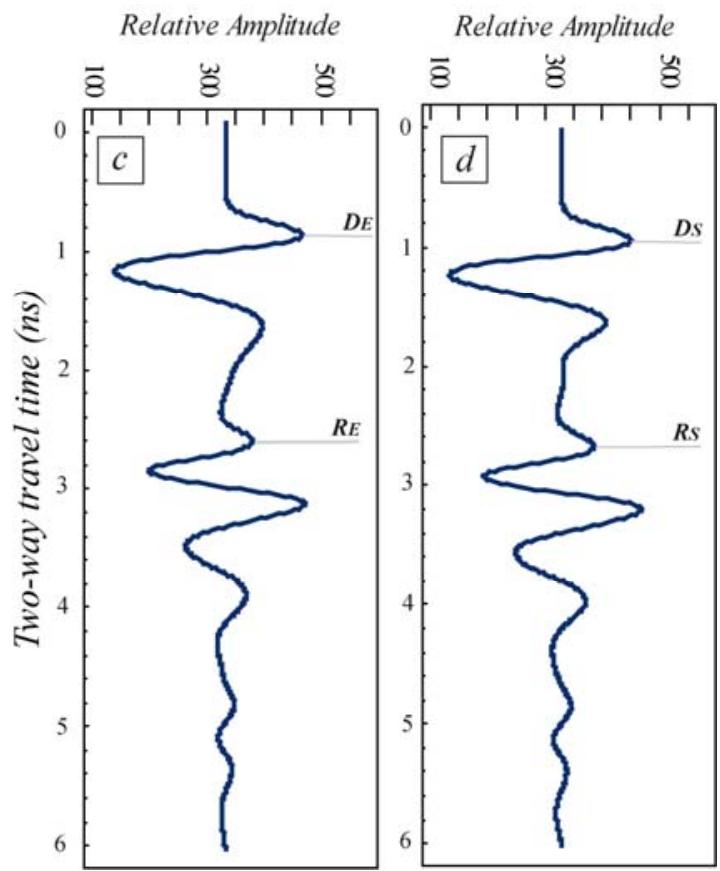

Figure 9 



Figure 10 


\section{Tables captions}

Tab. 1. Longitudinal $\left(\varepsilon^{\prime} /\right)$, tangential $\left(\varepsilon^{\prime}{ }_{T}\right)$ and radial $\left(\varepsilon_{R}^{\prime}\right)$ dielectric constant of various woods at different frequencies, moisture contents and grain directions.

Tab. 2. Names, following the European standard EN 13556:2003 (Round and sawn timber). Nomenclature of timbers used in Europe), dimensions and properties of the timber samples, when the moisture content was at hygroscopic equilibrium.

Table 3. Results from Test 1. Effect of the dielectric anisotropy of wood on wave parameters: velocities and dielectric constants

Table 4. Results from Test 1. Effect of the dielectric anisotropy of wood on wave amplitudes.

Table 5. Results from Test 2. Effect of the dielectric anisotropy of wood on wave parameters: velocities and dielectric constants.

Table 6. Results from Test 2. Effect of the dielectric anisotropy of wood on wave amplitudes.

Table 1

\begin{tabular}{|c|c|c|c|c|c|c|}
\hline \multirow{2}{*}{$\begin{array}{l}\text { WOOD } \\
\text { SPECIES }\end{array}$} & \multirow[t]{2}{*}{ FREQUENCY } & \multirow[t]{2}{*}{ TEMPERATURE } & \multirow{2}{*}{$\begin{array}{c}\text { MOISTURE } \\
\text { CONTENT }\end{array}$} & \multicolumn{3}{|c|}{$\begin{array}{l}\text { DIELECTRIC } \\
\text { PROPERTIES }\end{array}$} \\
\hline & & & & $\varepsilon^{\prime} / 1$ & $\varepsilon_{T}^{\prime}$ & $\varepsilon_{R}^{\prime}$ \\
\hline Poplar & $2.45 \mathrm{GHz}$ & $20^{\circ}-24^{\circ} \mathrm{C}$ & $12 \%$ & 2.49 & 1.84 & 2.03 \\
\hline Alder & $2.45 \mathrm{GHz}$ & $20^{\circ}-24^{\circ} \mathrm{C}$ & $12 \%$ & 2.87 & 2.17 & 2.37 \\
\hline Oriental beech & $2.45 \mathrm{GHz}$ & $20^{\circ}-24^{\circ} \mathrm{C}$ & $12 \%$ & 3.36 & 2.6 & 2.81 \\
\hline Douglas Fir & $50 \mathrm{MHz}$ & $25^{\circ} \mathrm{C}$ & 0 & 2.90 & 2.50 & 2.20 \\
\hline Douglas Fir & $50 \mathrm{MHz}$ & $25^{\circ} \mathrm{C}$ & $30 \%$ & 4.10 & 3.20 & 2.70 \\
\hline Oak & $50 \mathrm{MHz}$ & $25^{\circ} \mathrm{C}$ & 0 & 3.00 & 2.20 & 2.30 \\
\hline Oak & $50 \mathrm{MHz}$ & $25^{\circ} \mathrm{C}$ & $30 \%$ & 3.60 & 2.60 & 2.80 \\
\hline
\end{tabular}


Table 2

\begin{tabular}{|c|c|c|c|c|c|c|c|c|}
\hline \multirow[b]{2}{*}{$\begin{array}{l}\text { SAMPLE } \\
\text { CODE }\end{array}$} & \multirow{2}{*}{$\begin{array}{c}\text { GROUP } \\
\text { H/S* }\end{array}$} & \multicolumn{2}{|c|}{ NAME } & \multicolumn{3}{|c|}{ DIMENSIONS ${ }^{* *}$} & \multicolumn{2}{|c|}{ PROPERTIES } \\
\hline & & $\begin{array}{c}\text { Botanical } \\
\text { Specie }\end{array}$ & $\begin{array}{c}\text { English } \\
\text { Standardized }\end{array}$ & $\begin{array}{c}a \\
(\mathrm{~cm})\end{array}$ & $\begin{array}{c}b \\
(\mathrm{~cm})\end{array}$ & $\begin{array}{c}c \\
(\mathrm{~cm})\end{array}$ & $\begin{array}{c}\rho \\
\left(\mathrm{g} / \mathrm{cm}^{3}\right)\end{array}$ & $\begin{array}{l}M C \\
(\%)\end{array}$ \\
\hline 1 & $\mathrm{H}$ & $\begin{array}{l}\text { Eucalyptus globulus } \\
\text { Labill. }\end{array}$ & Southern blue gum & 14.2 & 7.6 & 14.0 & 0.90 & 9.0 \\
\hline 2 & $\mathrm{H}$ & $\begin{array}{l}\text { Erythrophleum ivorense } \\
\text { A. Chev. Sauveolens } \\
\text { (Guill\&Perr.) Brenan }\end{array}$ & Missanda & 19.5 & 11.6 & 19.0 & 0.81 & 10.6 \\
\hline 3 & $\mathrm{H}$ & $\begin{array}{l}\text { Eucalyptus globulus } \\
\text { Labill. }\end{array}$ & Southern blue gum & 23.9 & 7.3 & 23.5 & 0.80 & 10.7 \\
\hline 4 & $\mathrm{H}$ & $\begin{array}{l}\text { Erythrophleum ivorense } \\
\text { A. Chev. Sauveolens } \\
\text { (Guill\&Perr.) Brenan } \\
\end{array}$ & Missanda & 25.4 & 7.5 & 24.3 & 0.75 & 11.4 \\
\hline 5 & $\mathrm{~S}$ & Pinus pinaster Ait. & Maritime pine & 19.5 & 7.4 & 19.0 & 0.68 & 10.3 \\
\hline 6 & $\mathrm{H}$ & $\begin{array}{l}\text { Mansonia Altissima A. } \\
\text { Chev. }\end{array}$ & Mansonia & 20.1 & 6.1 & 20.3 & 0.67 & 11.1 \\
\hline 7 & $\mathrm{~S}$ & Pinus pinaster Ait. & Maritime pine & 19.6 & 7.3 & 19.1 & 0.66 & 10.5 \\
\hline 8 & $\mathrm{H}$ & $\begin{array}{l}\text { Eucalyptus globulus } \\
\text { Labill. }\end{array}$ & Southern blue gum & 14.1 & 7.3 & 13.9 & 0.65 & 10.5 \\
\hline 9 & $\mathrm{~S}$ & Pinus pinaster Ait. & Maritime pine & 19.6 & 7.1 & 19.1 & 0.64 & 12.8 \\
\hline 10 & $\mathrm{~S}$ & $\begin{array}{l}\text { Pinus nigra Arnold } \\
\text { subsp. }\end{array}$ & Corsican pine & 19.5 & 14.3 & 19.0 & 0.59 & 9.3 \\
\hline 11 & $\mathrm{H}$ & Prunus Serotina Ehrh. & American cherry & 32.2 & 8.0 & 31.9 & 0.58 & 10.4 \\
\hline 12 & $\mathrm{~S}$ & Pinus sylvestris L. & Redwood & 20 & 13.6 & 18.3 & 0.57 & 9.4 \\
\hline 13 & $\mathrm{H}$ & Acer campestre L. & Field maple & 18.1 & 8.0 & 18.0 & 0.56 & 10.1 \\
\hline 14 & $\mathrm{H}$ & Hallea ciliata & Abura & 30.4 & 8.0 & 30.9 & 0.56 & 13.2 \\
\hline 15 & $\mathrm{H}$ & $\begin{array}{l}\text { Amburama cearensis } \\
\text { (Fr. Allem) A. C. }\end{array}$ & Cerejeira & 14.5 & 10.0 & 14.0 & 0.55 & 10.7 \\
\hline 16 & $\mathrm{~S}$ & Pinus radiata D. Don & Radiata pine & 22.1 & 7.5 & 22.0 & 0.52 & 12.2 \\
\hline 17 & $\mathrm{~S}$ & Pinus radiata D. Don & Radiata pine & 19.2 & 6.8 & 19.2 & 0.50 & 9.5 \\
\hline 18 & $\mathrm{H}$ & Ochroma lagopus Sw. & Balsa & 20.9 & 10.0 & 20.9 & 0.12 & 10.5 \\
\hline
\end{tabular}

*H: Hardwood; S: Softwood; **a: width; b:thickness; c:lenght 
Table 3

\begin{tabular}{|c|c|c|c|c|c|c|}
\hline $\begin{array}{c}\text { SAMPLE } \\
\text { CODE }\end{array}$ & $\boldsymbol{v}_{/ \prime}{ }^{*}$ & $\boldsymbol{v}_{\perp}{ }^{*}$ & $\boldsymbol{v}_{/ /} \boldsymbol{v}_{\perp}$ & $\boldsymbol{\varepsilon}{ }^{\prime \prime}$ & $\boldsymbol{\varepsilon}_{\perp}{ }^{\prime}$ & $\boldsymbol{\varepsilon}_{/ /}{ }^{\prime} \boldsymbol{\varepsilon}_{\perp}{ }^{\prime}$ \\
\hline $\mathbf{1}$ & 15,6 & 18,1 & 0,9 & 3,7 & 2,8 & 1,3 \\
\hline $\mathbf{2}$ & 14,9 & 17,3 & 0,9 & 4,0 & 3,0 & 1,3 \\
\hline $\mathbf{3}$ & 15,4 & 16,9 & 0,9 & 3,8 & 3,2 & 1,2 \\
\hline $\mathbf{4}$ & 15,8 & 17,9 & 0,9 & 3,6 & 2,8 & 1,3 \\
\hline $\mathbf{5}$ & 17,3 & 19,2 & 0,9 & 3,0 & 2,5 & 1,2 \\
\hline $\mathbf{6}$ & 16,9 & 18,5 & 0,9 & 3,2 & 2,6 & 1,2 \\
\hline $\mathbf{7}$ & 16,7 & 19,4 & 0,9 & 3,2 & 2,4 & 1,3 \\
\hline $\mathbf{8}$ & 14,7 & 17,5 & 0,8 & 4,2 & 3,0 & 1,4 \\
\hline $\mathbf{9}$ & 17,2 & 19,4 & 0,9 & 3,0 & 2,4 & 1,3 \\
\hline $\mathbf{1 0}$ & 18,2 & 19,6 & 0,9 & 2,7 & 2,3 & 1,2 \\
\hline $\mathbf{1 1}$ & 17,5 & 21,0 & 0,8 & 2,9 & 2,0 & 1,4 \\
\hline $\mathbf{1 2}$ & 17,1 & 19,3 & 0,9 & 3,1 & 2,4 & 1,3 \\
\hline $\mathbf{1 3}$ & 18,5 & 20,5 & 0,9 & 2,6 & 2,1 & 1,2 \\
\hline $\mathbf{1 4}$ & 18,1 & 20,0 & 0,9 & 2,7 & 2,2 & 1,2 \\
\hline $\mathbf{1 5}$ & 18,6 & 20,6 & 0,9 & 2,6 & 2,1 & 1,2 \\
\hline $\mathbf{1 6}$ & 17,3 & 20,6 & 0,8 & 3,0 & 2,1 & 1,4 \\
\hline $\mathbf{1 7}$ & 17,8 & 20,0 & 0,9 & 2,8 & 2,3 & 1,3 \\
\hline $\mathbf{1 8}$ & 26,4 & 26,7 & 1,0 & 1,3 & 1,3 & 1,0 \\
\hline Average & 17,4 & 19,6 & 0,9 & 3,1 & 2,4 & 1,3 \\
\hline$\sigma^{* *}$ & 2,5 & 2,2 & 0,0 & 0,7 & 0,4 & 0,1 \\
\hline
\end{tabular}

Table 4

\begin{tabular}{|c|c|c|c|c|c|c|}
\hline $\begin{array}{c}\text { SAMPLE } \\
\text { CODE }\end{array}$ & $\boldsymbol{A}_{\boldsymbol{D} / /}$ & $\boldsymbol{A}_{\boldsymbol{D} \perp}$ & $\boldsymbol{A}_{\boldsymbol{D} / / / \boldsymbol{A}_{\boldsymbol{D} \perp}}$ & $\boldsymbol{A}_{\boldsymbol{R} / /}$ & $\boldsymbol{A}_{\boldsymbol{R} \perp}$ & $\boldsymbol{A}_{\boldsymbol{R} / / \boldsymbol{A}_{\boldsymbol{R} \perp}}$ \\
\hline $\mathbf{1}$ & 0,5 & 0,7 & 0,8 & 0,9 & 1,5 & 0,6 \\
\hline $\mathbf{2}$ & 0,6 & 0,7 & 0,8 & 0,5 & 0,8 & 0,7 \\
\hline $\mathbf{3}$ & 0,5 & 0,7 & 0,8 & 0,7 & 1,3 & 0,5 \\
\hline $\mathbf{4}$ & 0,6 & 0,8 & 0,8 & 0,7 & 1,3 & 0,5 \\
\hline $\mathbf{5}$ & 0,6 & 0,8 & 0,8 & 0,8 & 1,4 & 0,6 \\
\hline $\mathbf{6}$ & 0,6 & 0,8 & 0,8 & 1,3 & 2,0 & 0,7 \\
\hline $\mathbf{7}$ & 0,6 & 0,8 & 0,8 & 0,9 & 1,4 & 0,6 \\
\hline $\mathbf{8}$ & 0,5 & 0,7 & 0,7 & 1,0 & 1,6 & 0,6 \\
\hline $\mathbf{9}$ & 0,6 & 0,8 & 0,8 & 1,1 & 1,6 & 0,7 \\
\hline $\mathbf{1 0}$ & 0,7 & 0,8 & 0,9 & 0,6 & 1,0 & 0,6 \\
\hline $\mathbf{1 1}$ & 0,7 & 0,9 & 0,8 & 0,9 & 1,5 & 0,6 \\
\hline $\mathbf{1 2}$ & 0,7 & 0,8 & 0,8 & 0,5 & 0,8 & 0,6 \\
\hline $\mathbf{1 3}$ & 0,7 & 0,9 & 0,8 & 1,0 & 1,4 & 0,7 \\
\hline $\mathbf{1 4}$ & 0,6 & 0,8 & 0,8 & 0,8 & 1,3 & 0,6 \\
\hline $\mathbf{1 5}$ & 0,7 & 0,8 & 0,9 & 1,2 & 1,5 & 0,8 \\
\hline $\mathbf{1 6}$ & 0,7 & 0,8 & 0,8 & 0,8 & 1,5 & 0,5 \\
\hline $\mathbf{1 7}$ & 0,6 & 0,8 & 0,7 & 1,2 & 1,8 & 0,7 \\
\hline $\mathbf{1 8}$ & 0,9 & 1,0 & 0,9 & 1,1 & 1,4 & 0,8 \\
\hline Average & 0,6 & 0,8 & 0,8 & 0,9 & 1,4 & 0,6 \\
\hline $\boldsymbol{\sigma}$ & 0,1 & 0,1 & 0,0 & 0,2 & 0,3 & 0,1 \\
\hline
\end{tabular}


Table 5

\begin{tabular}{|c|c|c|c|c|c|c|}
\hline $\begin{array}{c}\boldsymbol{S A M P L E} \\
\boldsymbol{C O D E}\end{array}$ & $\boldsymbol{v}_{\boldsymbol{E}}{ }^{*}$ & $\boldsymbol{v}_{\boldsymbol{S}}{ }^{*}$ & $\boldsymbol{v}_{\boldsymbol{E}} / \boldsymbol{v}_{\boldsymbol{S}}$ & $\boldsymbol{\varepsilon}_{\boldsymbol{E}}{ }^{\prime}$ & $\boldsymbol{\varepsilon}_{\boldsymbol{S}}{ }^{\prime}$ & $\boldsymbol{\varepsilon}_{\boldsymbol{E}}{ }^{\prime} \boldsymbol{\varepsilon}_{\boldsymbol{S}}{ }^{\prime}$ \\
\hline $\mathbf{1}$ & 19,2 & 18,7 & 1,0 & 2,4 & 2,6 & 0,9 \\
\hline $\mathbf{2}$ & 18,0 & 17,8 & 1,0 & 2,8 & 2,8 & 1,0 \\
\hline $\mathbf{3}$ & 16,1 & 15,5 & 1,0 & 3,5 & 3,7 & 0,9 \\
\hline $\mathbf{4}$ & 16,5 & 15,6 & 1,1 & 3,3 & 3,7 & 0,9 \\
\hline $\mathbf{5}$ & 21,0 & 19,8 & 1,1 & 2,0 & 2,3 & 0,9 \\
\hline $\mathbf{6}$ & 21,8 & 22,2 & 1,0 & 1,9 & 1,8 & 1,0 \\
\hline $\mathbf{7}$ & 21,5 & 20,4 & 1,1 & 1,9 & 2,2 & 0,9 \\
\hline $\mathbf{8}$ & 18,9 & 18,1 & 1,0 & 2,5 & 2,8 & 0,9 \\
\hline $\mathbf{9}$ & 20,6 & 19,4 & 1,1 & 2,1 & 2,4 & 0,9 \\
\hline $\mathbf{1 0}$ & 19,9 & 20,4 & 1,0 & 2,3 & 2,2 & 1,1 \\
\hline $\mathbf{1 1}$ & 22,8 & 21,9 & 1,0 & 1,7 & 1,9 & 0,9 \\
\hline $\mathbf{1 2}$ & 21,2 & 20,1 & 1,1 & 2,0 & 2,2 & 0,9 \\
\hline $\mathbf{1 3}$ & 21,6 & 21,2 & 1,0 & 1,9 & 2,0 & 1,0 \\
\hline $\mathbf{1 4}$ & 18,1 & 17,7 & 1,0 & 2,8 & 2,9 & 1,0 \\
\hline $\mathbf{1 5}$ & 21,0 & 20,9 & 1,0 & 2,0 & 2,1 & 1,0 \\
\hline $\mathbf{1 6}$ & 22,5 & 22,2 & 1,0 & 1,8 & 1,8 & 1,0 \\
\hline $\mathbf{1 7}$ & 22,2 & 22,2 & 1,0 & 1,8 & 1,8 & 1,0 \\
\hline $\mathbf{1 8}$ & 27,8 & 28,7 & 1,0 & 1,2 & 1,1 & 1,1 \\
\hline Average & 20,6 & 20,2 & 1,0 & 2,2 & 2,3 & 1,0 \\
\hline $\boldsymbol{\sigma}^{* *}$ & 2,7 & 3,0 & 0,0 & 0,6 & 0,7 & 0,1 \\
\hline
\end{tabular}

Table 6

\begin{tabular}{|c|c|c|c|c|c|c|}
\hline $\begin{array}{c}\text { SAMPLE } \\
\text { CODE }\end{array}$ & $\boldsymbol{A}_{\boldsymbol{D E}}$ & $\boldsymbol{A}_{\boldsymbol{D S}}$ & $\boldsymbol{A}_{\boldsymbol{D E}} / \boldsymbol{A}_{\boldsymbol{D S}}$ & $\boldsymbol{A}_{\boldsymbol{R E}}$ & $\boldsymbol{A}_{\boldsymbol{R S}}$ & $\boldsymbol{A}_{\boldsymbol{R E}} / \boldsymbol{A}_{\boldsymbol{R S}}$ \\
\hline $\mathbf{1}$ & 0,7 & 0,6 & 1,2 & 0,3 & 0,4 & 0,9 \\
\hline $\mathbf{2}$ & 0,7 & 0,8 & 0,9 & 0,4 & 0,4 & 1,0 \\
\hline $\mathbf{3}$ & 0,7 & 0,8 & 0,9 & 0,4 & 0,3 & 1,3 \\
\hline $\mathbf{4}$ & 0,7 & 0,8 & 0,9 & 0,4 & 0,2 & 1,6 \\
\hline $\mathbf{5}$ & 0,8 & 0,7 & 1,2 & 0,1 & 0,1 & 1,2 \\
\hline $\mathbf{6}$ & 0,8 & 0,8 & 1,0 & 0,1 & 0,1 & 0,9 \\
\hline $\mathbf{7}$ & 0,8 & 0,7 & 1,1 & 0,1 & 0,1 & 1,0 \\
\hline $\mathbf{8}$ & 0,8 & 0,6 & 1,2 & 0,3 & 0,4 & 0,7 \\
\hline $\mathbf{9}$ & 0,8 & 0,7 & 1,1 & 0,1 & 0,1 & - \\
\hline $\mathbf{1 0}$ & 0,8 & 0,8 & 1,0 & 0,7 & 0,6 & 1,0 \\
\hline $\mathbf{1 1}$ & 0,8 & 0,9 & 0,9 & 0,0 & 0,0 & 1,3 \\
\hline $\mathbf{1 2}$ & 0,8 & 0,8 & 1,1 & 0,5 & 0,6 & 0,8 \\
\hline $\mathbf{1 3}$ & 0,8 & 0,8 & 1,1 & 0,3 & 0,3 & 0,8 \\
\hline $\mathbf{1 4}$ & 0,7 & 0,8 & 0,8 & 0,2 & 0,2 & 0,9 \\
\hline $\mathbf{1 5}$ & 0,8 & 0,8 & 1,1 & 0,9 & 1,0 & 0,9 \\
\hline $\mathbf{1 6}$ & 0,8 & 0,8 & 1,1 & 0,2 & 0,1 & 1,2 \\
\hline $\mathbf{1 7}$ & 0,8 & 0,7 & 1,1 & 0,2 & 0,1 & 1,2 \\
\hline $\mathbf{1 8}$ & 1,0 & 1,0 & 1,0 & 0,4 & 0,4 & 1,1 \\
\hline Average & 0,8 & 0,8 & 1,0 & 0,3 & 0,3 & 1,0 \\
\hline $\boldsymbol{\sigma}$ & 0,1 & 0,1 & 0,1 & 0,2 & 0,2 & 0,2 \\
\hline
\end{tabular}

